\title{
Evolution and Architecture of Blue Nile Basin Using Integrated Gravity, Reflection Seismic and Wire Line Logs
}

\author{
Mohamed NE ${ }^{1 *}$, Mohamed Ali OM ${ }^{1}$, Zaroug I² and Ibrahim AE \\ ${ }^{1}$ Faculty of Petroleum and Minerals, AINeelain University, Sudan \\ ${ }^{2}$ Petrodar Operation Company, Sudan
}

\begin{abstract}
Parts of the Blue Nile basin showed good oil indications a decade ago, the puzzling question is why no oil draining The common geological sense will go towards the lateral lithologic variations and its impacts on the porosity and permeability and thus towards the dynamics of the processes that governs and generate this architecture and the modes of its development. This study aims to reveal the basin architecture and its evolution, and it strongly suggests the application of constrained 2D backstripping technique using process oriented gravity modeling (POGM) technique and use the discrimination between the rift and sediment anomalies. By decompaction stratigraphic seismic sections, isostasy, recover the geometry of the crust at time of rift, calculating and adding the contribution of sediments and water to rift gravity anomaly, compare between the observed free air and the calculated gravity. POGM technique results a good discrimination between sediment and rift gravity contributions, and a value of $45 \mathrm{~km}$ thickness of elastic lithosphere, which is used to constrain the backstripping technique. Results from the backstripping shows the basin is a half graben type, the extension factor varies from 1.04 up to 1.1 , which is accommodated by listric normal fault and the rotated blocks which compromise the hanging wall and developed to be the basin. The relative movement between these blocks and the foot wall goes different behaviors from acting independently to act as one unit this interplay change the normal faults into reverse faults, made temporal segmentation of the basin, relief, internal drainage patterns and migration of basin depocentre. From a tectonostratigraphic point of view, the Blue Nile basin evolution is given by different paleoenviroments and their positions in terms of time and space are controlled by interplay of sediment supply and basin capacity which are climatic and structural/thermal subsidence dependents respectively.
\end{abstract}

Keywords: Evolution; Architecture; Backstripping; Blue Nile; Basin

\section{Introduction}

Sedimentary basins are regions of earth crust dominated by subsidence, which give rise to erosion processes and sediments accumulation, where vast and huge amount of the oil, gas and water store in it. These natural reserves encourage multi-disciplinary geoscientists continuously to develop and refine the understanding of processes that initiate and develop these basins, their fill and stratigraphy.

From the point of a view of lithospheric processes there are two major groups of basins: basins due to lithospheric stretching belonging to rift drift suite, and basins formed primarily by flexure of continental and oceanic lithosphere [1]. Several models, those proposed by McKenzie (pure shear model) and Wernicke (simple shear) flexural cantilever model [2,3], study and explain the evolution and modes of formation, and how these modes govern the basin architecture. Although they vary in approach but all agree that basin development refer to the lithosphere response (deformation) to stretching and loads, which is governed by its physical state.

The Blue Nile basin is considered as a continental rift basin. Filling and stratigraphic architecture of such basins exhibit all or part of a tripartite stratigraphy type due to basin dynamics, sediment flux and basin capacity. To have more detailed understanding of the spatial and temporal impacts of the basin dynamics upon stratigraphy various studies were done on the scope of oil exploration in this block. The main objective of this study is to reveal the Blue Nile basin architecture and evolution, and this falls in four folds: to constrain the parameterization of the 2D backstripping technique regarding the lithospheric elastic thickness of the Blue Nile Basin using the Process Oriented Gravity Modeling (POGM) method, to conduct the constrained 2D backstripping technique to study the evolution of the Blue Nile Basin in term of temporal and spatial basin fill and stratigraphy, and to have discrimination of the rift and sediment gravity anomalies.

\section{Geology and structural setting}

The study area, lies between latitudes $13^{\circ} 10^{\prime}-13^{\circ} 40^{\prime}$ and longitudes $33^{\circ} 50^{\prime}-34^{\circ} 20^{\prime} \mathrm{E}$, is a of part of Block- 8 which in turn a part of the Blue Nile Basin member of central Sudan rift system with a general strike trend NW (Figure 1), it is situated in the eastern central Sudan it is around $300 \mathrm{~km}$ SE Khartoum. No high relief or exposures, the area is flat bounded by the Blue Nile from the west and dissected by the Dinder, Rahad rivers and their tributaries, the area average elevation is $400 \mathrm{~m}$ above the sea level. Most of it is covered by Tertiary/Quaternary sediments (Gezera and Umrwaba formations).

The continent of Africa has experienced a complex history of rifting since the Protrozoic. The Mesozoic saw the fragmentation of Gondwana, with major phases of rifting in Africa resulting in the development of West and Central African rifts system during Jurassic-Cretaceous times [4,5]. Parts of Central and East Africa Have experienced at least two or more episodes of rift [6]. The deep lineament and shear patterns of Sudan follow two main NNW (Red Sea trend) and NNE (gulf of Aden Trend) Precambrian mobile belts trend NE and NW of Paleozoic sediments occupy NE-SW aligned grabens, Mesozoic continental sediments with NW Palaeotrends were deposited

*Corresponding author: Mohamed NE, Faculty of Petroleum and Minerals, AINeelain University, Sudan, E-mail: nuhazein@hotmail.com

Received October 01, 2014; Accepted October 29, 2014; Published October 31, 2014

Citation: Mohamed NE, OM MA, Zaroug I, Ibrahim AE (2014) Evolution and Architecture of Blue Nile Basin Using Integrated Gravity, Reflection Seismic and Wire Line Logs. J Geophys Remote Sensing 4: 137. doi: 10.4172/2169-0049.1000137

Copyright: (c) 2014 Mohamed NE, et al. This is an open-access article distributed under the terms of the Creative Commons Attribution License, which permits unrestricted use, distribution, and reproduction in any medium, provided the original author and source are credited. 
Citation: Mohamed NE, OM MA, Zaroug I, Ibrahim AE (2014) Evolution and Architecture of Blue Nile Basin Using Integrated Gravity, Reflection Seismic and Wire Line Logs. J Geophys Remote Sensing 4: 137. doi:10.4172/2169-0049.1000137

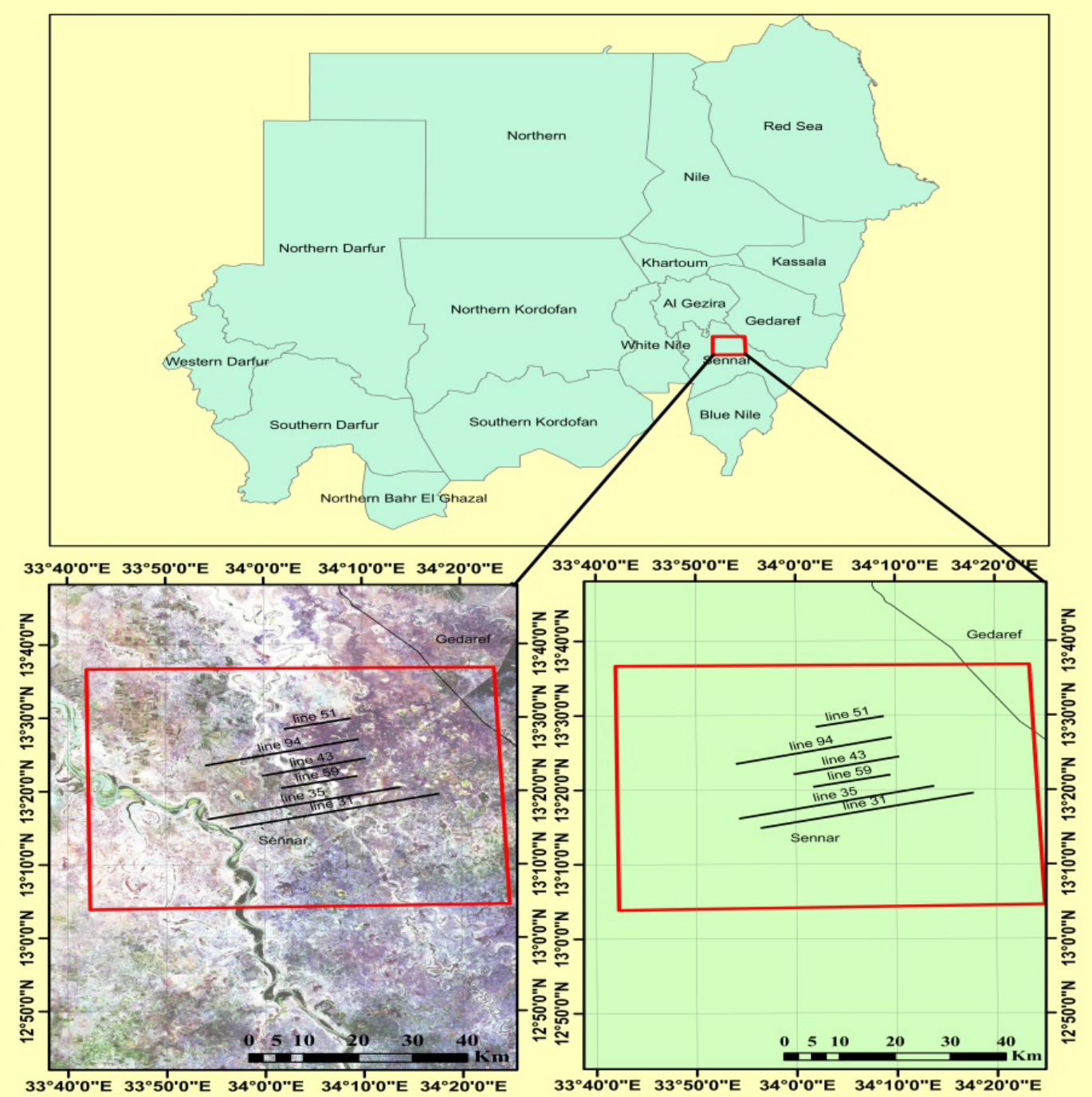

Figure 1: Location map of the study area showing the interpreted seismic lines.

in depressions also aligned NW. Cenozoic uplift and volcanism were associated with domal uplift along NE and SE axes [7].

The Blue Nile basin development suggested to be accompanied to Central African Shear Zone (CASZ) due to the breakup of Gondwana Land with many Sudan interior rift basins [6] where Umm Hani Shear Zone (UHSZ) forms its southern boundary, and the tectonic subsidence results from normal listric faults originating within the deep crust or mantle [8]. The filling of the basin was approximated to be as continental basin, sediments which represented by the lacustrine, fluvial and alluvial deposits favoring the climatic conditions dominate in the exact time and their spatial distribution is controlled by the tectonics and sediment flux. From the intensive activities of oil exploration, now the sedimentary sequences rest unconformable on the basement complex is well known.

The Blue Nile evaporate bearing Formation represents a partly restricted lake system, mostly basinal to shallow marginal conditions (Table 1). The Lower Dinder formation, may represent an open lacustrine system, basinal part with intermittent, shallowing to reach the oxidation zones. The Middle Dinder formation represents a shallowing up facies, decrease in lake levels, with common development of red beds and soils. The Upper Dinder formation represent a late stage of lake filling by enormous clastic feeding systems and development of red soil intercalations (post-flooding events). The Middle/Late Cretaceous Damazin formation represents a dominant fluvial system on marginal lake during lake abandonment stage (WINPOC, 2005) [9].

\section{Used Methods and Techniques}

Two techniques are applied in this study, Backstripping technique which consider as a reliable tool for studying geo-history and evolution, and the Process Oriented Gravity Modeling technique (POGM) which is applied to constrain the Backstripping and can be extended to have a discrimination of rift and sediment contribution.

\section{Back stripping technique}

The sediment and water loads above a horizon of interest in a 
Citation: Mohamed NE, OM MA, Zaroug I, Ibrahim AE (2014) Evolution and Architecture of Blue Nile Basin Using Integrated Gravity, Reflection Seismic and Wire Line Logs. J Geophys Remote Sensing 4: 137. doi:10.4172/2169-0049.1000137

Page 3 of 10

\begin{tabular}{|c|c|c|c|c|c|c|}
\hline \multirow[t]{2}{*}{ Formation } & & \multirow[t]{2}{*}{ AGE } & \multicolumn{2}{|c|}{ DINDER-1 Well } & \multicolumn{2}{|c|}{ HOSSN-1 Well } \\
\hline & & & Top & Thickness & Top & Thickness \\
\hline \multirow[t]{2}{*}{ Post-damazin } & & POSSIBLE TERTIARY & SURFACE & $165 \mathrm{~m}$ & SURFACE & $50 \mathrm{M}$ \\
\hline & Unconformity & & & & & \\
\hline \multirow[t]{2}{*}{ Damazin } & & TURONIAN-LOWER SENONIAN & $165 \mathrm{~m}$ & $210 \mathrm{~m}$ & $50 \mathrm{~m}$ & $209 \mathrm{~m}$ \\
\hline & Unconformity & & & & & \\
\hline \multirow[t]{2}{*}{ DINDER -I (Upper) } & & ALBIAN-CENOMANIAN & $366 \mathrm{~m}$ & $1502 \mathrm{~m}$ & $259 \mathrm{~m}$ & $731 \mathrm{~m}$ \\
\hline & Unconformity & & & & & \\
\hline \multirow[t]{2}{*}{ DINDER -I (Lower) } & & BARREMIAN & & & & \\
\hline & Unconformity & & & & & \\
\hline \multirow[t]{2}{*}{ DINDER -II } & & NEOCOMIAN & $1868 \mathrm{~m}$ & $748 \mathrm{~m}$ & $990 \mathrm{~m}$ & $839 \mathrm{~m}$ \\
\hline & Unconformity & & & & & \\
\hline \multirow[t]{2}{*}{ DINDER -III } & & LATE JURASSIC & $2616 \mathrm{~m}$ & $841 \mathrm{~m}$ & $1829 \mathrm{~m}$ & $726 \mathrm{~m}$ \\
\hline & Unconformity & & & & & \\
\hline \multirow[t]{2}{*}{ BLUE NILE } & & MIDDLE/LATE JURASSIC & $3475 \mathrm{~m}$ & $785 \mathrm{~m}$ & $2555 \mathrm{~m}$ & $356 \mathrm{~m}$ \\
\hline & Unconformity & & & & & \\
\hline BASIN FILL* & & $\begin{array}{cc}\text { EARLY } & \text { JURASSIC- } \\
& \text { PALEOZOIC?* }\end{array}$ & & & & \\
\hline \multicolumn{3}{|c|}{ *Seismic Marker, not penetrated. } & \multicolumn{2}{|c|}{ TD $4242 \mathrm{~m}$} & \multicolumn{2}{|c|}{ TD $2911 \mathrm{~m}$} \\
\hline
\end{tabular}

Table 1: Based on boreholes and geophysical data the ideal stratigraphic column of the DINDER-1 and HOSSN-1 wells, in Block 8 .

sedimentary basin causes an isostatic affect so that the total subsidence observed is made of a tectonic driving force component and sedimentary/water loads components. Watt and Rayan [10] were the first to propose the isolation of the tectonic driving force by removal of the isostatic effects of the sediments and loads and called the technique backstripping. 1D well backstripping uses information on the lithologies, ages, depths of deposition of the main stratigraphic units, at a point location to quantitatively estimate the depth that basement would be in the absence of sediment and water loading.

Here a combination of $1 \mathrm{D}$ and $2 \mathrm{D}$ backstripping is used to calculate both the stretching factor $(\beta)$ and the isolation of the total tectonic subsidence (TTS) and use them in deducing the crustal thickness, which is modeled with sediment thicknesses. Recovering the basement depth in the absence of the sediment and water loads by balancing the pressures at the base of the decompacted and backstripped columns, then

$$
\rho_{\mathrm{w}} \mathrm{gW}_{\mathrm{d}}+\overline{\rho_{\mathrm{s}}} \mathrm{g} \mathrm{S} *+\mathrm{t}{ }_{\mathrm{c}} \rho_{\mathrm{c}} \mathrm{g}=\mathrm{TTS} \rho_{\mathrm{w}} \mathrm{g}+\rho_{\mathrm{m}} \mathrm{gZ}{ }_{\mathrm{m}}+\mathrm{t}{ }_{\mathrm{c}} \rho_{\mathrm{c}} \mathrm{g}(1)
$$

If an airy isostatic model is assumed, where the masses of stretched and unstretched lithosphere are balanced everywhere across the rift basin and the densities of the crust and mantle do not vary with temperature, a simple expression can be derived from equation (1), which directly relates the amount of stretching, $\beta$, to the basin's TTS,

$$
\beta^{-1}=1-\frac{\operatorname{TTS}\left(\rho_{m}-\rho_{w}\right)}{t\left(\rho_{m}-\rho_{c}\right)}
$$

Where $\mathrm{Z}_{\mathrm{m}}$ Mantle thickness above the compensation depth, TTS Total Tectonic Subsidence, $\mathrm{W}_{\mathrm{d}}$ Water depth, $\mathrm{S}^{*}$ Decompacted thickness, $\rho_{\text {s }}$ Average density of a particular sediment layer, S Present-day layer thickness, g Average gravity, $\rho_{\mathrm{m}}$ Mantle density at $0^{\circ} \mathrm{C}\left(3.33 \mathrm{~g} / \mathrm{cm}^{3}\right), \rho_{\mathrm{w}}$ Sea-water density $\left(1.03 \mathrm{~g} / \mathrm{cm}^{3}\right), \rho_{\mathrm{c}}$ Crust density at $\left.0^{\circ} \mathrm{C} 2.8 \mathrm{~g} / \mathrm{cm}^{3}\right), \rho_{\text {a }}$ Asthenosphere density at $1333^{\circ} \mathrm{C}\left(3.3 \mathrm{~g} / \mathrm{cm}^{3}\right), \mathrm{t}_{\mathrm{c}}$ Crustal thickness, and $\beta$ Uniform stretching factor.

In the perspective of this study, and of POGM in general, the TTS corresponds to the position of the basement in the absence of surface (e.g. sedimentary) and sub-surface (e.g. under plating) loading $[9,10]$. Therefore, once these loads have been backstripped from the present day basin configuration, Equation (2) can be used to recover the geometry of the basin at the time of rifting, which is defined by the
TTS and the back striped Moho [11]. This process repeated varying the values of the elastic lithosphere thickness $\left(\mathrm{T}_{\mathrm{e}}\right)$, the proposed $\mathrm{T}_{\mathrm{e}}$ values were $15 \mathrm{~km}, 30 \mathrm{~km}, 45 \mathrm{~km}, 60 \mathrm{~km}, 75 \mathrm{~km}$ (Figure 2). More information on $1 \mathrm{D}$ and $2 \mathrm{D}$ backstripping are explained in $[3,11]$, respectively.

\section{Process Oriented Gravity Modeling techniques (POGM)}

In this study the use of gravity fall in two parts first to constrain the thickness of the elastic lithosphere, second correlate the isolated sediment anomaly across the strike of the basin in other words gravity anomalies used to discriminate the sediment contribution and rift contribution to the basin anomaly.

Applying two dimensional forward modeling using the interpreted 2D seismic sections to calculate the gravity anomaly, which utilize line integral method for a semi-infinite slab model as described in [12]. In this technique, the gravity anomaly of an arbitrary shape 2-D body is obtained by adding the contributions from thin, horizontal, semi-infinite layers defined by the edges of the body (Table 2). This is illustrated for a simple polygonal shape in Figure 3, and the gravity contribution from any single interface is given by:

$$
U_{\mathrm{D}}=a_{1} \sin \phi_{1} \cos \phi_{1}\left[\theta_{1}-\theta_{2}+\tan \phi_{1} \mathrm{~h} \frac{\cos \theta_{1}\left(\tan \theta_{1}-\tan \phi_{1}\right)}{\cos \theta_{2}\left(\tan \theta_{2}-\tan \phi_{1}\right)}\right.
$$

And finally,

$$
\Delta \mathrm{g}=2 \mathrm{G} \Delta \rho\left(\mathrm{U}_{\mathrm{R}}+\mathrm{U}_{\mathrm{B}}+\ldots+\mathrm{U}_{\mathrm{il}}\right)
$$

Watts [11] suggested a method, dubbed Process-Oriented Gravity Modeling (POGM) that does not require a priori estimates of the paleobathymetry. The method regards passive margins as simple mechanical systems in which the crust thinned during rifting is subsequently subject to sediment (i.e. the non-volcanic type passive margin), volcanic (i.e. volcanic margin) or some combination of these loads.

Flexural backstripping (i.e. backstripping that explicitly takes into account the strength of the lithosphere) of the sediment reveals the Total Tectonic Subsidence (TTS) at a margin and, hence, the geometry of the rifted crust for different assumed values of $T_{e}$. By calculating the 'sum' gravity anomaly due to the combined effects of the restored 
Citation: Mohamed NE, OM MA, Zaroug I, Ibrahim AE (2014) Evolution and Architecture of Blue Nile Basin Using Integrated Gravity, Reflection Seismic and Wire Line Logs. J Geophys Remote Sensing 4: 137. doi:10.4172/2169-0049.1000137

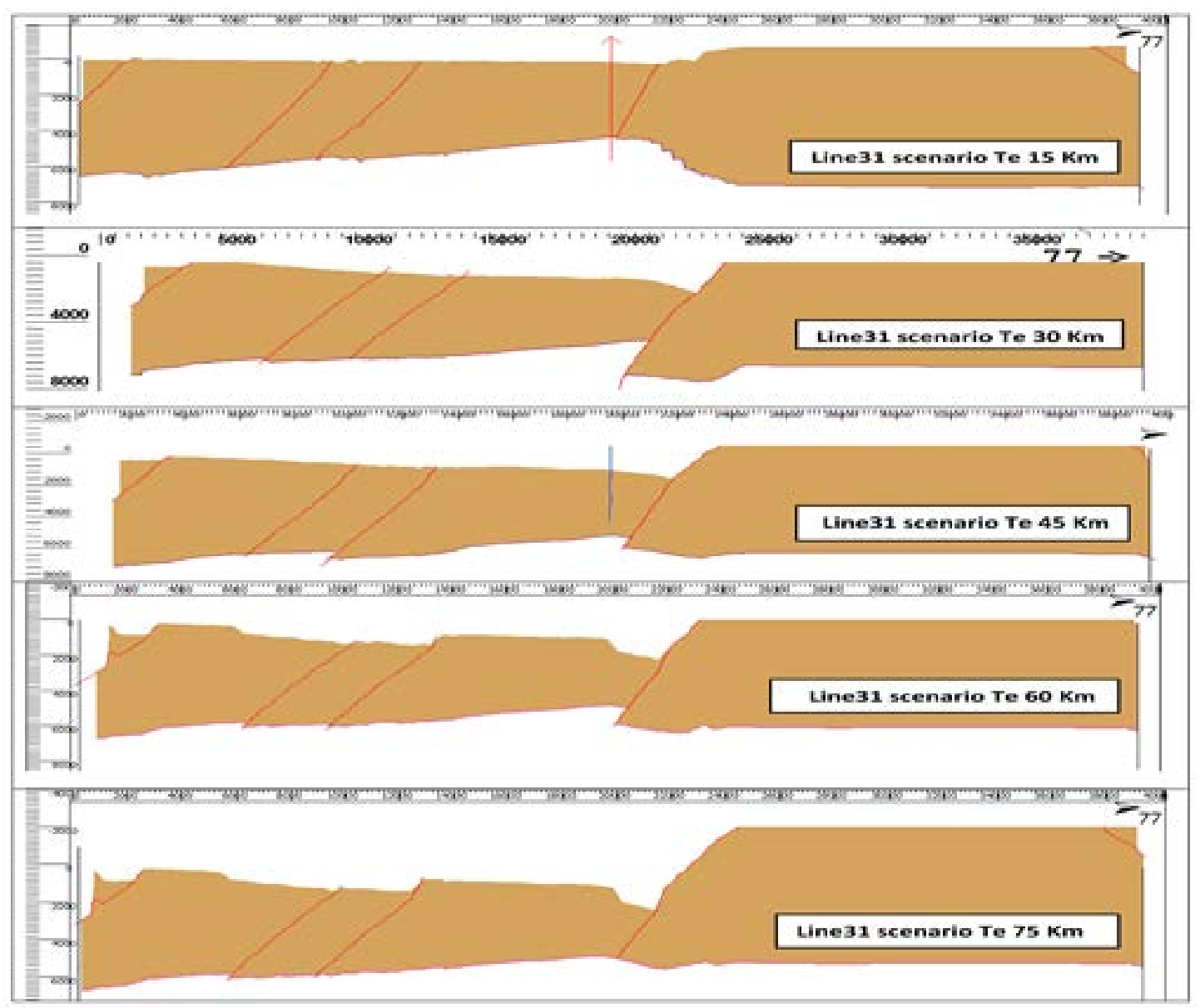

Figure 2: Five scenarios resulted by POGM repeated process varying the values of the elastic lithosphere thickness (Te) which are: $15 \mathrm{~km}, 30 \mathrm{~km}, 45 \mathrm{~km}, 60 \mathrm{~km}, 75 \mathrm{~km}$.

\begin{tabular}{|c|c|c|c|c|c|c|c|}
\hline Horizon & Color & Velocity & K Value & Depth coefficient & porosity & Age & Thickness \\
\hline superficial & & 1500.00 & 0.50 & 0.39 & 0.59 & 60 & 475.00 \\
\hline Marker.2.-1 & & 1500.00 & 0.50 & 0.30 & 0.51 & 80 & 899.00 \\
\hline Marker.5.-1 & & 1500.00 & 0.50 & 0.39 & 0.56 & 115 & 462.00 \\
\hline Marker.6.-1 & & 1500.00 & 0.50 & 0.42 & 0.57 & 125 & 549.00 \\
\hline Marker.8.-1 & & 1500.00 & 0.50 & 0.50 & 0.63 & 144 & 133.00 \\
\hline Marker.9.-1 & & 1500.00 & 0.50 & 0.50 & 0.62 & 180 & 1280.00 \\
\hline Basement & & 1500.00 & 0.50 & 0.00 & 0.00 & 300 & 4000.00 \\
\hline
\end{tabular}

Table 2: The used data base for seismic line 31 in 2D-Move software which applies a 2D flexural model.

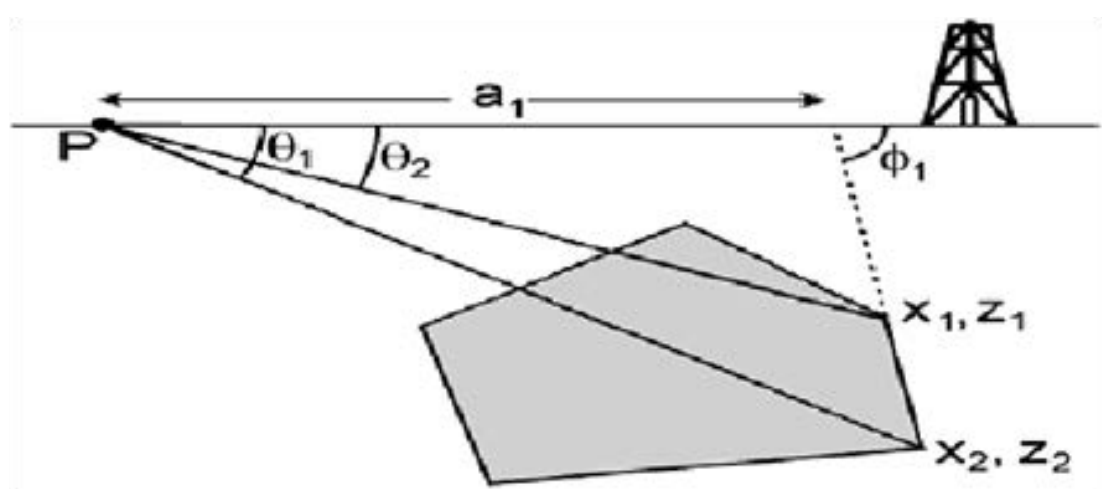

Figure 3: Simple polygonal shape and gravity contribution from single interface 
Citation: Mohamed NE, OM MA, Zaroug I, Ibrahim AE (2014) Evolution and Architecture of Blue Nile Basin Using Integrated Gravity, Reflection Seismic and Wire Line Logs. J Geophys Remote Sensing 4: 137. doi:10.4172/2169-0049.1000137

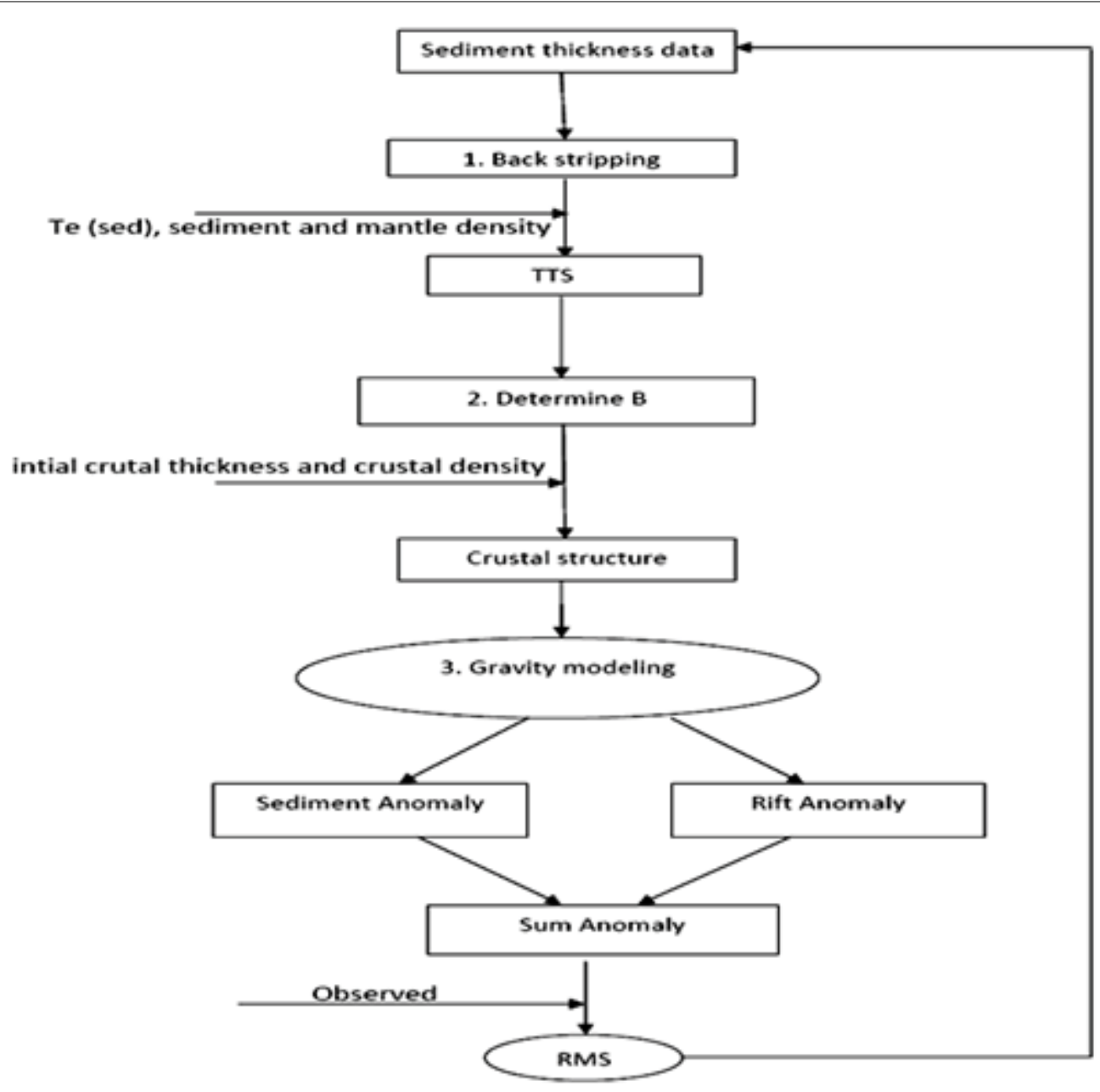

Figure 4: The POGM method illustration and its flow work.
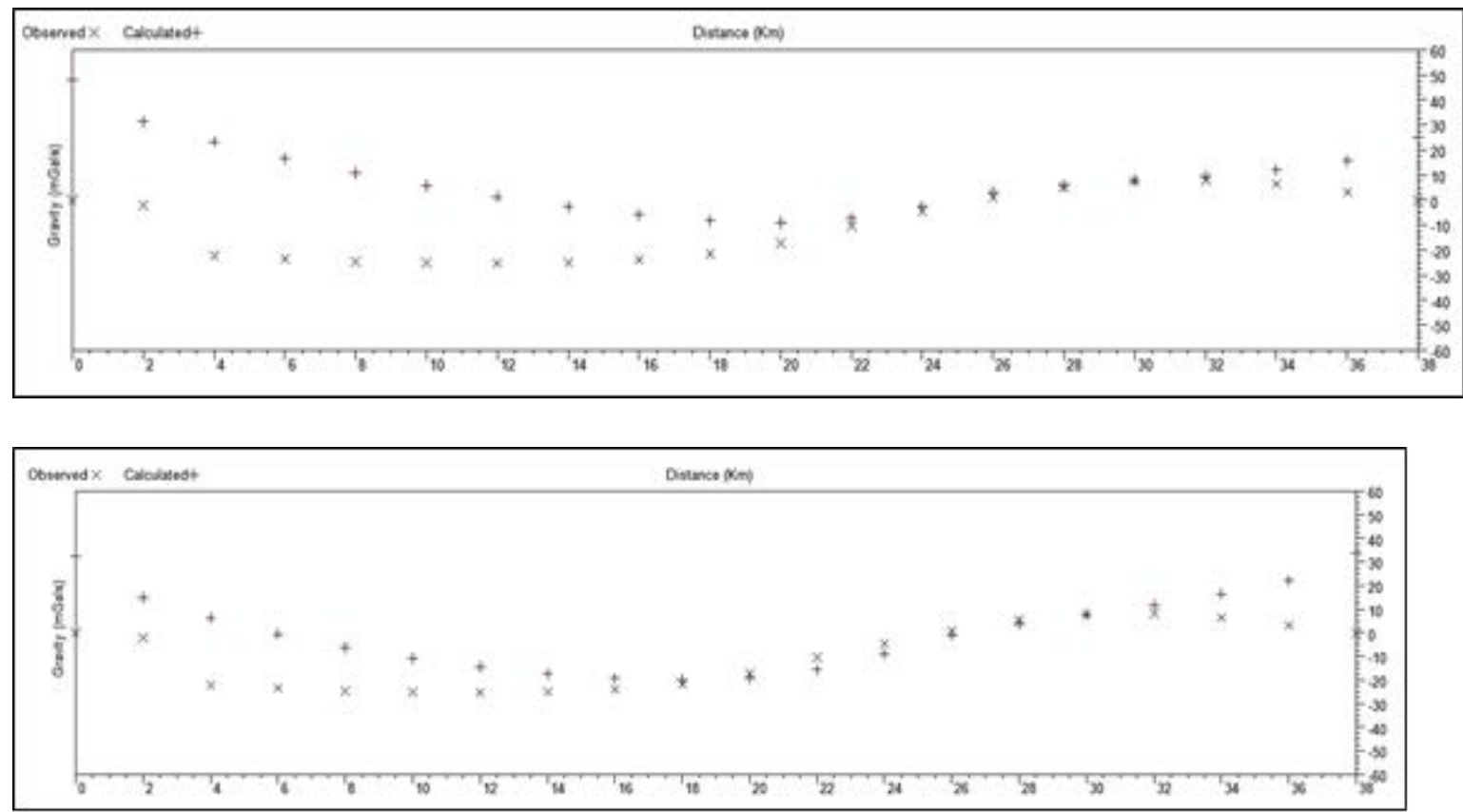
Citation: Mohamed NE, OM MA, Zaroug I, Ibrahim AE (2014) Evolution and Architecture of Blue Nile Basin Using Integrated Gravity, Reflection Seismic and Wire Line Logs. J Geophys Remote Sensing 4: 137. doi:10.4172/2169-0049.1000137
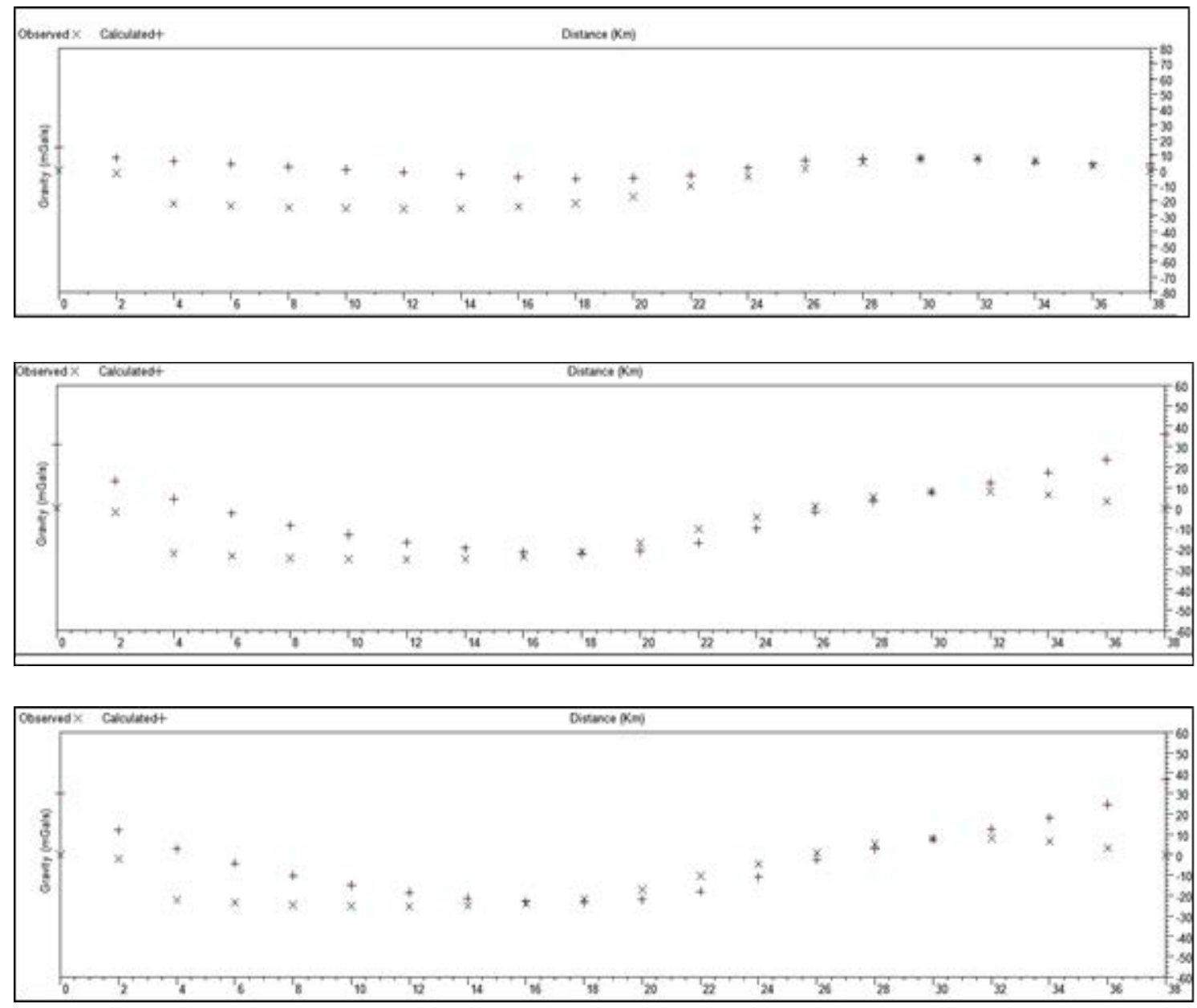

Figure 5: Observed Free air gravity values compared to the calculated data at varied $\mathrm{T}_{\mathrm{e}}$ values.

\section{Te versus $R M S_{T_{e}}$ values}

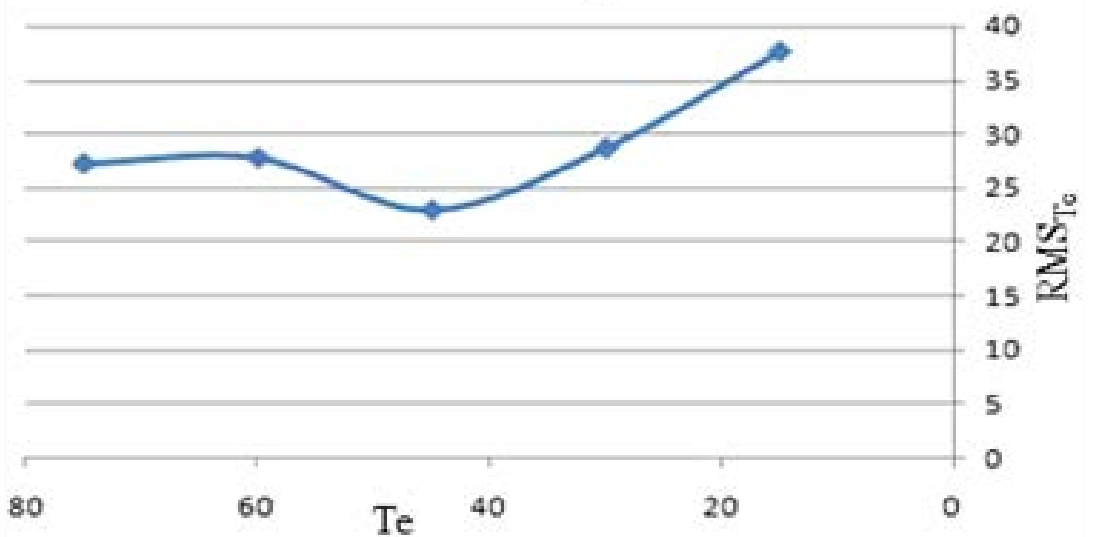

Figure 6: $T_{e}$ versus RMS $T_{e}$ values and selecting the least RMS value when the elastic lithospheric thickness (Te) is $45 \mathrm{~km}$.

rifted crust (the "rifting anomaly") and sediments (the "sedimentation anomaly") and comparing it to observations, it is possible to constrain $\mathrm{T}_{\mathrm{e}}$ at the margin. The effects of magmatic underplating and sub-aerial volcanism can be included in POGM by computing their flexural loading effect on both the TTS and the gravity anomaly.

\section{Results}

Five calculated RMS values are observed based on the suggested elastic lithosphere thickness $\left(\mathrm{T}_{\mathrm{e}}\right.$ ). As in the POGM flow work (Figure 4 ), the gravity contribution of the rift and sediment anomalies is 
Citation: Mohamed NE, OM MA, Zaroug I, Ibrahim AE (2014) Evolution and Architecture of Blue Nile Basin Using Integrated Gravity, Reflection Seismic and Wire Line Logs. J Geophys Remote Sensing 4: 137. doi:10.4172/2169-0049.1000137
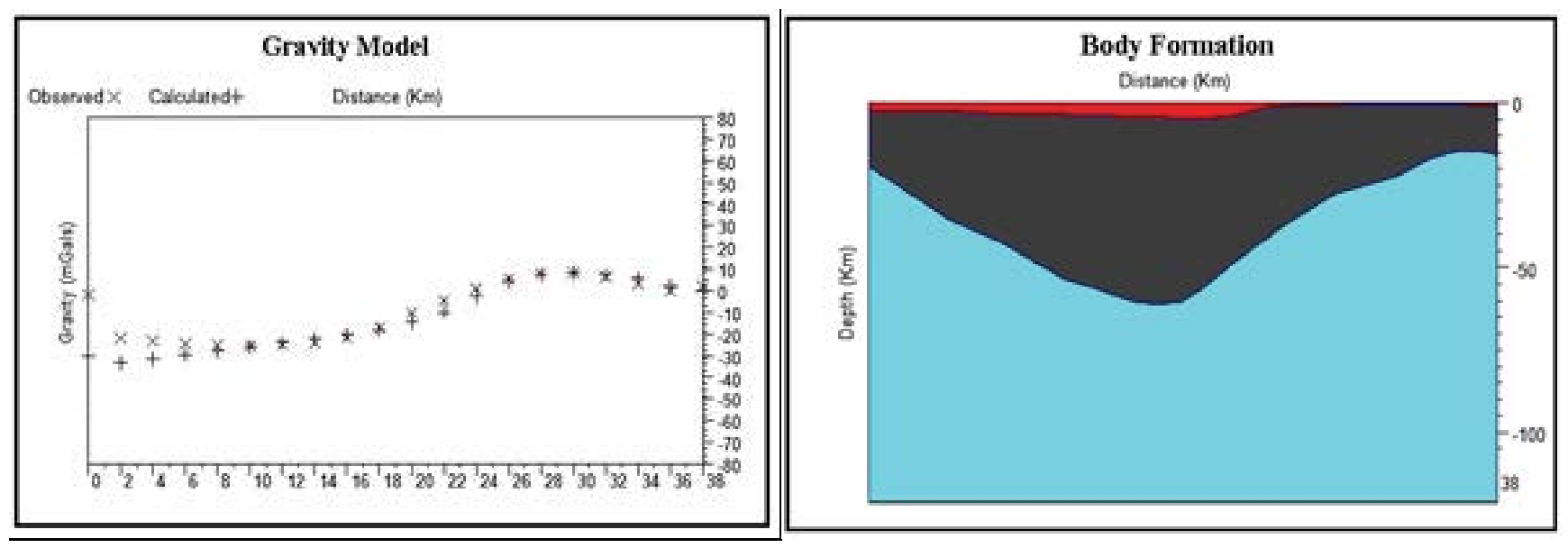

Figure 7: 2D Gravity model of both calculated and observed gravity values when $T_{e}$ is $45 \mathrm{~km}$.

\begin{tabular}{|c|c|c|c|}
\hline FORMATION & Colous & Age & $A G E$ \\
\hline DAMAZIN & & இ & TURONAAN-LOWER SENONAN- POSSIBLE TERTIARY \\
\hline DINDER - 1 (Uppe $)$ & & 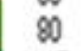 & ALBLAN-CENOMANZAN \\
\hline DINDER-1(LOWER) & & 115 & BARREMAAN \\
\hline DNDER - $\mathbb{Z}$ & & 125 & NEOCOMIAN \\
\hline DANDERIII & & 144 & LATE תRASSC \\
\hline BLUE NILE & & 100 & PALEOZOIC?• BARLY -ADDLELATE JURASSIC \\
\hline BASEMENT & & 300 & PALEOZOIC \\
\hline
\end{tabular}

Figure 8: Stratigraphic column of the Blue Nile Basin adopted in this study.

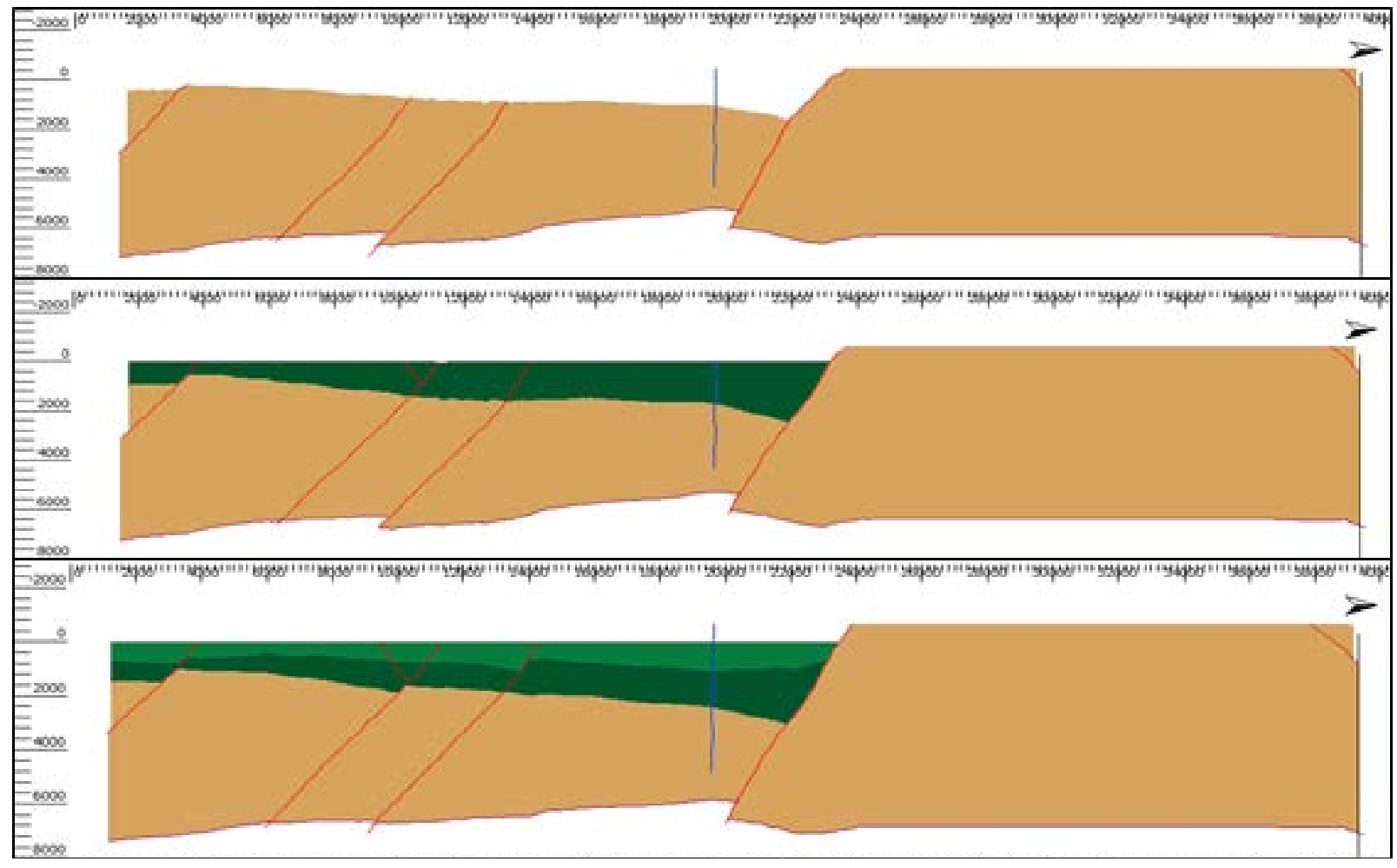


Citation: Mohamed NE, OM MA, Zaroug I, Ibrahim AE (2014) Evolution and Architecture of Blue Nile Basin Using Integrated Gravity, Reflection Seismic and Wire Line Logs. J Geophys Remote Sensing 4: 137. doi:10.4172/2169-0049.1000137

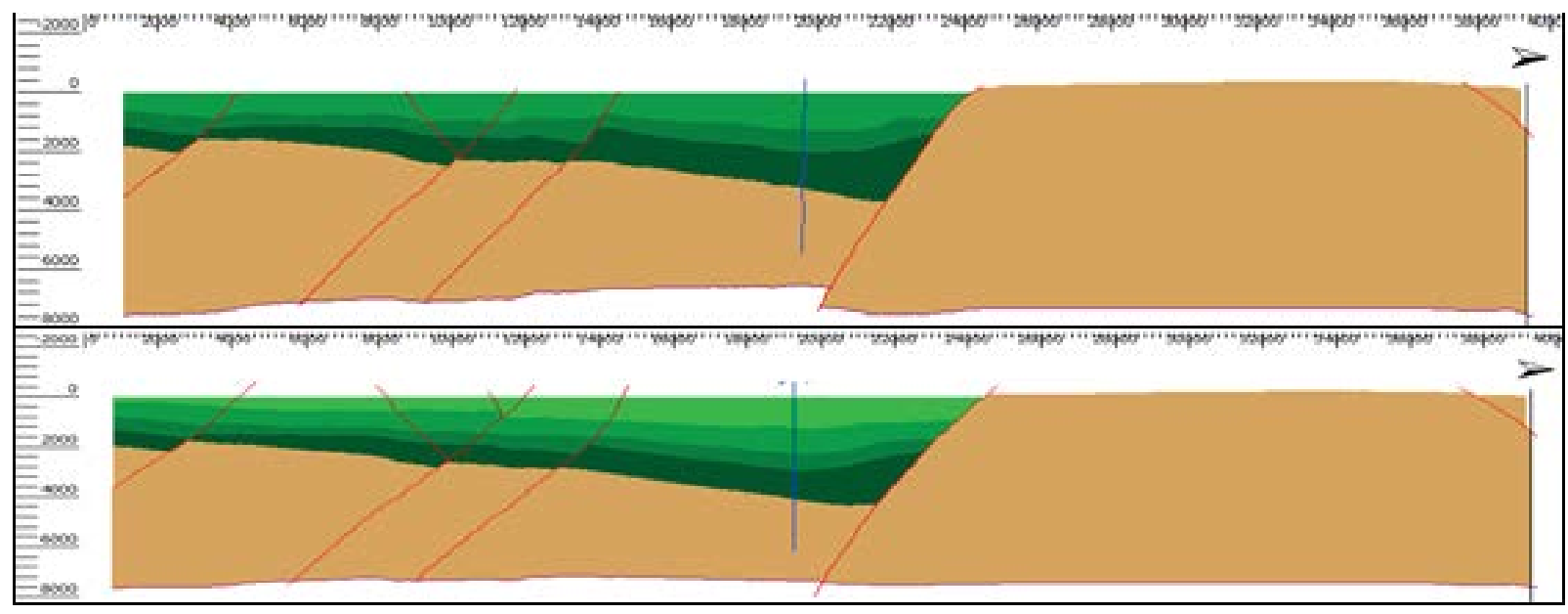

Figure 9: The basin evolution of the Blue Nile from stage (a) to (g).

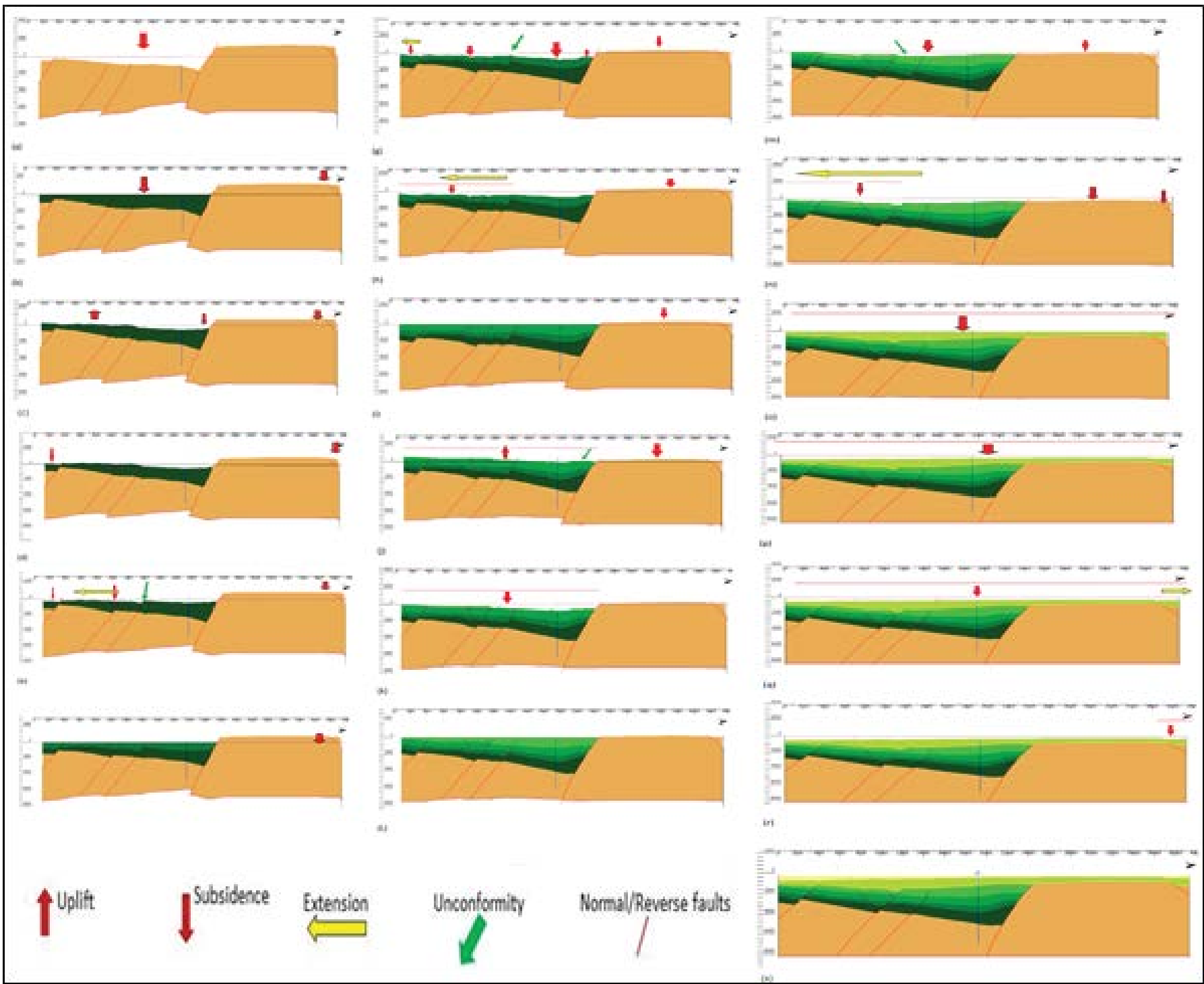

Figure 10: Tectono-stratigraphy evolution of the Blue Nile basin from (a) to (s). 
deduced using forward gravity modeling technique. The calculated results at varied Te values from the five scenarios $(15,30,45,60$, and 75 $\mathrm{km})$ are summed and compared with the observed gravity anomalies (Figure 5). The RMS values are plotted versus its Te values, the least RMS indicates the best model and thus its value is used to constrain the backstripping (Figures 6 and 7).

The (POGM) used constrains upon sediment thickness from seismic and the recovered crust geometry using backstripping, the backstripped line represent the inter space area between the backstripped lines, so the deduced rift anomaly value could be deducted from the observed anomaly values of that area and having the sediment contribution.

Backstripping conducted as tool for studying the basin evolution, Backstripping is a technique employed to analyse the subsidence history of extensional basins, and involves the progressive removal of sediment loads, incorporating the isostatic and sediment decompaction responses to this unloading. The results of backstripping calculations using 1D models employing local (Airy) isostasy and 2D models employing 'flexural' isostasy

The fundamental difference between Airy isostasy, used in 1D modeling, and flexural isostasy, used in 2D modelling, is that in the 1D approach isostatic loads are compensated locally, i.e. immediately beneath the load, while with the flexural approach loads are distributed regionally. In extensional basins subsidence histories produced by backstripping are usually interpreted in terms of the lithospheric stretching model of McKenzie [2], in which lithosphere stretching gives rise to crustal thinning and elevation of the geotherm.

Typically the McKenzie lithosphere extension model assumes a rapid period of syn-rift extension, coincident with surface faulting, followed by a period of slower time-dependent post-rift subsidence, during which the thermal anomaly, associated with the elevated geotherm from rifting, cools in an exponential manner with a time constant of c. $65 \mathrm{Ma}$. This episode of post-rift thermal subsidence causes significant subsidence of the basin floor for 150-200 Ma after the rift event itself. the advantage of the 2D flexural Backstripping is Lateral sampling at scales of $1 \mathrm{~km}$ or less can, however, readily be provided by 2D data (cross-sections) based on interpreted seismic lines.

In this study process oriented gravity modeling technique is used to constrain the thickness of elastic lithosphere $\left(\mathrm{T}_{\mathrm{e}}\right)$ which deduced to be $45 \mathrm{~km}$ and by applying this value using the software 2D move, the following are the resultant cross sections showing the stratigraphy of the sediments and the depth to the basement at each time (Figure 8).

The basin evolution of the Blue Nile is illustrated in several stages (Figure 9a-9g). The first stage (a) shows the tectonic subsidence due stretching results in a half graben its slope towards the foot wall. Where stage (b) shows the deposition of Blue Nile formation and it fills the basin up to the brim and the sediments fining would be expected towards the foot wall. The following stage (c) Dinder Formatiom III overlies the Blue Nile formation after a period of erosion and isostatic adjustment results in segmented the section in three parts taken paleo drainage into account suggestions could be in isolated sub basin environments in lower parts of the formation. The uplift results in depocentre migration in stage (d) which will give rise to variation in the sedimentary environments. The unification of the basin and slightly changes in the depocentre is observed in stage (e) due to the uplift and the basin extension and isostatic compensation. More basin extension and depocentre migration results in stage $(\mathrm{f})$ in variation in the dinderI thickness and facies changes. The basin capacity exceeds the sediment supply. And finally the basin reaches the tectonic equilibrium and no more subsidence in stage ( $\mathrm{g}$ ) and only filling of the depression.

From the conducted backstripping the extension is accommodated by half graben model which is represented by master normal listric fault which result in footwall shown to the right of the section and the hanging wall which subdued forming the basin and it is comprise the rotating blocks (Domino type). The mutual relationship between the foot wall and the hanging wall is very complicated through time and space and this complication is not a result to the tectonic subsidence and the thermal contraction and sediment loading only but it arises from the fact that the hanging wall is composed of three blocks that at time it behave as one block and at other times they interact independently, and the angle of the listric faults separating the blocks may be one of the governing factors of this mutual interrelationship movement (Figure 9). In this phase of the study the subsidence is going to be described qualitatively, the aim is to see the spatial and temporal distribution of subsidence and basin extension.

The geohistory analysis (Figure 10) shows that this part of the basin passes different episodes of subsidence shown by the red down ward arrows where the uplift shown by the red upward arrows and extension shown with the yellow arrows, the interaction between the rotating blocks which compromise the basin (the hanging wall), the foot wall block and the sediment loading in the early to late Jurassic results in sub basins and yet the basin may not act as a one unit. By the basin middle age (Neocomian - Barremian and Albian - Cenomanian, Turonian - Llower Senonian) the basin unified to some extent in one depocentre which shifted towards the foot wall. In the following episodes the (Turonian -Lower Senonia, possible Tertiary) depocentre shifted towards the middle of the basin. The basin pass in the earlier and middle ages four phases of extension the main one which initiate the basin and the other three represented by the yellow arrows. The green arrows pointed to the unconformities evidences, the normal faults act as reverse faults and the erosion which result in distinguished shaping of the formations, Also the depocentre migration due to the phases of uplifts. The evolution animation of the Blue Nile basin result in calculated crustal thickness ranging from 30 to $70 \mathrm{~km}$, and the stretching factor vary from 1.04 to 1.1 and four rift phases evidenced by disconformities and extensions as shown in Figure 10.

\section{Conclusion and Discussion}

The study concluded that although there is a limitation in applying the Mackinze model for the calculation, to recover the geometry of the crust by applying $1 \mathrm{D}$ backstripping and use the deduced values to calculate the gravity values which compared with observed ones, and have the least RMS to indicate and constrain the $\mathrm{T}$ value, and used it in another model (The Cantilever Model) to conduct $2 \mathrm{D}$ backstripping, But still the technique is a good mean to have a good approximation on the basin evolution and architecture and as tool to animate the basin structure and stratigraphy. The evolution animation of the tectonostratigraphy of the Blue Nile basin result in calculated crustal thickness ranging from 30 to $70 \mathrm{~km}$, and the stretching factor vary from 1.04 to 1.1 and four rift phases evidenced by disconformities and extensions

The results gave a good idea about what will be on the other areas of the basin, this obviously can be seen from the normal listric faults which segment the hanging wall (the basin) into many blocks, and it's complicated relative movement due to their inter tongue, this turned the normal faults in some parts as a reverse ones, which affect greatly the basement topography so there are isolated areas and scarps which give rise to varied depositional sedimentary environments, on 
Citation: Mohamed NE, OM MA, Zaroug I, Ibrahim AE (2014) Evolution and Architecture of Blue Nile Basin Using Integrated Gravity, Reflection Seismic and Wire Line Logs. J Geophys Remote Sensing 4: 137. doi:10.4172/2169-0049.1000137

Page 10 of 10

the temporal scope it results in uplift of some parts which give rise to erosion and a new phase of sedimentation process. The migration of the basin depocentre, unification the basin into one, the end of the sub basin era expected to furnish varied depositional environments.

Since the two extremes of the continental rift basins sediments are sand and clays, it is suggested to have a more refined subsidence determinations by applying the 1D inverse method determining lithospheric strain rate variation at different times scales to values deduced by backstripping and correlated with a borehole data and AVO in and, so a stratigraphic and structural, animations, models and maps could be generated. These techniques can be extended to see the adjacent basins interrelations on temporal and spatial basis.

\section{Acknowledgement}

The Pan American Center for Earth and Environmental Sciences (PACES) is highly appreciated for providing this study the Talwani Software (v.2.3) [13] Our appreciation reaches PETRODAR Workstation in Sudan where the 2D Move Backstripping part was conducting.

\section{References}

1. Allen PA, Allen JR (2005) Basin analysis, principles and applications. Blackwell Scientific Publications, Oxford.

2. McKenzie DP (1978) Some remarks on the development of sedimentary basins. Earth Planet Sci Lett 40: 25-32.

3. Roberts AM, Kusznir NJ, Yielding G, Styles P (1998) 2D flexural backstripping of extensional basins: the need for a sideways glance. Petroleum Geoscience 4: 327-338.

4. Schull TJ (1988) Rift basins of interior Sudan: Petroleum exploration and discovery. Am. Assoc Pet Geol Bull 72: 1178-1182.

5. Bosworth W (1992) Mesozoic and early Tertiary rift tectonics in East Africa. Tectonophysics 209: 115-137.

6. Ibrahim AE, Ebinger CJ, Fairhead JD (1996) Lithospheric, extension northwest of the Central African Shear Zone in Sudan from potential field studies. Tectonophysics 225: 79-97.

7. Salama RB (1985) Buried troughs, grabens in Sudan. Journal of African Earth Sciences 3: 381-390.

8. Mann DC (1989) Thick-skin and Thin-skin Detachment faults in continental Sudanese Rift Basins. Journal of African Earth Science 8: 307-332.

9. White Nile (5B) Petroleum Operating Company "WNPOC" (September 2005) volume 1 text (geological, geophysical \& geochemical studies). Prepared by Earth Resources Exploration "EREX".

10. Watts AB, Karner GD, Steckler MS (1982) Lithospheric flexure and the evolution of sedimentary basins. Phil Trans R Soc Lond A 305: 249-281.

11. Watts $A B$ (1988) Gravity anomalies: crustal structure and flexure of the lithosphere at the Baltimore Canyon Trough.. Earth Planet Sci Lett 89: 221-238.

12. Stewart J, Watts AB, Bagguley J (2000) Three-dimensional subsidence analysis and gravity modeling of the continental margin offshore Namibia. Geophys J Int 141: 724-746.

13. Talwani M, Eldholm O (1973) Boundary between Continental and Oceanic Crust at the Margin of Rifted Continents Nature 241: 325-330. 